\title{
Pengaruh Staffing Sebagai Salah Satu Fungsi Manajemen di Mitra Jaya Company Terhadap Kinerja Karyawan
}

\author{
Hanivan Sabtaji ${ }^{1}$, Siti Azizah ${ }^{2}$ \\ 1Program Studi Peternakan, Fakultas Peternakan, Universitas Brawijaya, Malang, \\ Indonesia. \\ 2Program Studi Peternakan, Fakultas Peternakan, Universitas Brawijaya, Malang, \\ Indonesia. \\ Jalan Veteran, Ketawanggede, Lowokwaru, Kota Malang, Jawa Timur. 65145 \\ Email: siti.azizah@ub.ac.id
}

\begin{abstract}
Mitra Jaya Company is a company located in Malang City and is engaged in animal husbandry by producing egg incubators. The descriptive statistical analysis and multiple linear regression analysis methods were used in this study. Based on theseresult, the recruitmen, selection, training, reward and punishment, as well as development simultaneously have huge impact on Mitra Jaya Company employee performance. The t-test results show a t-Cal 2,936 as well as a significance value 0,007 between the recruitment variable and the employee performance variable. Based on these results, the recruitmen have huge impact on Mitra Jaya Company employee performance. The t-test between the selection variable and the employee performance variable yielded a t-Cal 2,228 and a significance value 0.036. Same as recruitment, the selection variables have huge impact on Mitra Jaya Company employee performance. The training variable's t-test generated $t$-Cal $-0,149$, with a significant value 0,883, indicating that the training variable has no impact on employee performance. Then $t$ test results on the reward and punishment variable including development obtained a $t$ Cal 1.699, with such a significant value 0,102 and a $t$-Cal 0.531 with significant value 0,601. Based on these results, the reward, punishment and development variables have no huge impact on Mitra Jaya Company employee performance.
\end{abstract}

Keywords: Staffing, Employee Performance, Management

\begin{abstract}
Abstrak
Mitra Jaya Company adalah sebuah perusahaan yang terletak di Kota Malang dan bergerak di bidang peternakan dengan memproduksi mesin tetas telur. Penelitian ini menggunakan analisis statistik deskriptif dan analisis regresi linear untuk mengetahui pengaruh komponen staffing terhadap kinerja karyawan. Berdasarkan hasil yang didapatan, variabel bebas rekrutmen, seleksi, pelatihan, reward dan punishment, serta pengembangan secara bersama - sama memiliki pengaruh yang signifikan terhadap kinerja karyawan. Sedangkan hasil uji-t menunjukan $t_{\text {hitung }}$ sebesar 2,936 dengan signifikansi 0,007 antara variabel rekrutmen dengan kinerja karyawan. Berdasarkan hasil tersebut, variabel rekrutmen memiliki pengaruh yang besar terhadap kinerja
\end{abstract}


karyawan. Hasil thitung pada variabel seleksi sebesar 2,228 dan signifikansi sebesar 0,036. Sama seperti variabel rekrutmen, berdasarkan hasil tersebut dapat disimpulkan bahwa variabel seleksi memiliki pengaruh yang signifikan terhadap kinerja karyawan. Variabel pelatihan mendapatkan hasil uji-t dengan $t_{\text {hitung }}$ sebesar $-0,149$ dan signifikansi 0,883 yang mengindikasikan bahwa variabel pelatihan tidak memberikan pengaruh pada kinerja karyawan. Kemudian pada variabel reward dan punishment mendapatkan hasil uji-t dengan thitung sebesar 1,699 dengan signifikasnsi 0,102. Sedangkan pada variabel pengembangan mendapatkan hasil uji-t dengan $t_{\text {hitung }}$ 0,531 dan signifikasnsi 0,601. Berdasarkan hasil tersebut, variabel reward dan punishment serta pengembangan tidak memiliki pengaruh yang besar terhadap kinerja karyawan.

Kata kunci: Staffing, kinerja karyawan, manajemen

\section{PENDAHULUAN}

Mitra Jaya Company merupakan sebuah perusahaan yang terletak di Kota Malang dan bergerak di bidang peternakan dengan memproduksi mesin tetas telur. Mitra Jaya Company didirikan pada tahun 1990. Sejak awal berdirinya perusahaan ini bernama Mitra Jaya dan berganti menjadi Mitra Jaya Company sejak tahun 2007. Di awal berdirinya, Mitra Jaya Company hanya mampu memproduksi mesin tetas telur dalam jumlah yang kecil sebanyak 20 unit/bulan dengan teknologi yang digunakan untuk memproduksi mesin tetas telur masih menggunakan peralatan yang sederhana. Saat ini, Mitra Jaya Company mampu menghasilkan mesin tetas telur sebanyak 1000 unit/bulan. Dalam menjalankan usahanya, Mitra Jaya Company menggunakan karyawan sebagai sumber daya manusia yang sudah memenuhi standar perusahaan melalui beberapa tahapan untuk mendapatkan sumber daya manusia yang baik. Dalam ilmu manajemen proses untuk mendapatkan sumber daya manusia yang baik dapat dilakukan dengan staffing. Menurut Firmansyah dan Mahardika (2018) menyatakan staffing adalah suatu proses yang berhubungan dengan proses rekrutmen, seleksi, dan orientasi atau sosialisasi serta penempatan karyawan untuk mengisi sumber daya manusia dari tingkat manajer hingga karyawan. Untuk mendapatkan sumber daya manusia yang andal, maka organisasi perlu melakukan perekrutan calon karyawan. Dengan adanya proses staffing, maka tujuan dari perusahaan akan tercapai dengan memaksimalkan kinerja karyawan dalam melakukan aktivitas produksi.

Berdasarkan penjelasan di atas, rumusan masalah dalam penelitian ini adalah bagaimana pengaruh staffing pada proses rekrutmen, seleksi, pelatihan, reward dan punishment, serta pengembangan sebagai salah satu fungsi manajemen terhadap kinerja karyawan di Mitra Jaya Company dalam memproduksi produk mesin tetas telur. Sedangkan tujuan tujuan penelitian ini adalah untuk mengetahui bagaimana pengaruh staffing pada proses rekrutmen, seleksi, pelatihan, reward dan punishment, serta pengembangan sebagai salah satu fungsi manajemen terhadap kinerja karyawan di Mitra Jaya Company dalam memproduksi mesin tetas telur

\section{KAJIAN TEORI}

Sumber daya manusia merupakan faktor yang penting dalam kelangsungan kegiatan perusahaan. Dalam suatu perusahaan, sumber daya manusia perlu mendapatkan perhatian yang lebih karena dapat mempengaruhi produktivitas perusahaan itu sendiri sehingga sumber daya manusia memegang peranan penting dalam setiap aktivitas 
organisasi. Menurut Findarti (2016) menjelaskan bahwa sumber daya manusia memiliki peranan yang penting dalam suatu kegiatan organisasi. Apabila di dalam organisasi didukung dengan sarana dan prasarana serta sumber daya yang berlebih, tetap tidak terselesaikan dengan baik apabila tidak mendapat dukungan dari sumber daya manusia yang andal. Hal ini dapat disimpulkan bahwa sumber daya manusia merupakan kunci pokok yang harus mendapatkan perhatian lebih berdasarkan kebutuhannya. Sebagai kunci pokok, sumber daya manusia menentukan keberhasilan pelaksanaan kegiatan organisasi. Menurut Hariandja dalam Lolowang (2016) menjelaskan bahwa sumber daya manusia merupakan proses perencanaan dan pengembangan untuk mencapai tujuan individu dan organisasi. Sumber daya manusia adalah salah satu faktor penting dalam suatu organisasi selain modal yang perlu dikelola dengan baik untuk meningkatkan efektivitas dan efisiensi dalam organisasi. Dalam ilmu manajemen sumber daya manusia terdapat salah satu fungsi yaitu staffing. Staffing menurut Sinambela (2016) adalah proses ketika sebuah organisasi memastikan jumlah karyawan yang bekerja memiliki kemampuan (skill) yang dibutuhkan untuk melaksanakan pekerjaan yang benar, di waktu yang benar, untuk mencapai tujuan organisasi. Sedangkan menurut Firmansyah dan Mahardika (2018) menyatakan staffing adalah suatu proses yang berhubungan dengan proses rekrutmen, seleksi, dan orientasi atau sosialisasi serta penempatan karyawan untuk mengisi sumber daya manusia dari tingkat manajer hingga karyawan. Untuk mendapatkan sumber daya manusia yang andal, maka organisasi perlu melakukan perekrutan calon karyawan.

Rekrutmen dilakukan dengan menyertakan kriteria - kriteria umum dan khusus yang memiliki keterkaitan dengan tanggung jawab yang diterima. Ketika sudah mendapatkan sumber daya manusia yang sesuai dengan kriteria, organisasi dapat melakukan seleksi guna mendapatkan sumber daya manusia yang baik. Menurut Randal dan Susan dalam Anawati, (2016) menjelaskan bahwa proses rekrutmen merupakan sebuah upaya yang dilakukan perusahaan untuk mencari sejumlah karyawan yang memenuhi syarat tertentu sehingga perusahaan dapat melakukan seleksi untuk mengisi lowongan yang sudah ada. Rekrutmen dimulai ketika perusahaan memerlukan tenaga kerja dan membuka lowongan sampai perusahaan mendapatkan calon karyawan yang diinginkan sesuai kriteria yang sudah ditentukan dengan memenuhi kualifikasi sesuai jabatan yang ada. Selain itu menurut Purwati dan Satria (2017) menjelaskan bahwa calon karyawan yang direkrut dan diseleksi diharapkan menghasilkan produktivitas dan kinerja yang tinggi. Perekrutan dan seleksi tenaga kerja harus berkualitas dan sesuai dengan bidang yang ditempatinya.

Suatu perusahaan memerlukan sumber daya manusia yang memiliki produktivitas yang tinggi sehingga dapat bekerja secara efektif dan efisien dalam melakukan aktivitas produksi. Untuk mencapai kinerja yang efektif dan efisien, maka diperlukan suatu program seperti pelatihan, pemberian reward dan punishment, serta pengembangan bagi semua karyawan sehingga menciptakan sumber daya manusia yang baik. Menurut Sunarsi (2018) menjelaskan bahwa pelatihan merupakan salah satu upaya yang dilakukan untuk meningkatkan kinerja sumber daya manusia yang dimiliki. Pelatihan juga merupakan siklus yang harus dilakukan secara terus menerus dalam jangka waktu tertentu guna menyeimbangkan perkembangan perusahaan dan sumber daya manusia yang dimiliki sehingga dapat terus seirama dengan arah perkembangan organisasi. Sedangkan menurut Muhlis dkk (2018) menjelaskan bahwa pelatihan merupakan proses pendidikan jangka pendek dengan prosedur yang sistematis dan terorganisir, dimana pegawai non manajerial mempelajari keterampilan guna menambah pengetahuan dalam tujuan terbatas. Tujuan pelatihan yang dilakukan oleh perusahaan adalah untuk 
memperbaiki dan mengembangkan sikap, tingkah laku, keterampilan, dan pengetahuan para pekerja sesuai dengan keinginan perusahaan. Berbeda dengan pelatihan, pengembangan adalah aktivitas yang dilakukan perusahaan untuk memfasilitasi karyawan dalam memenuhi tuntutan pekerjaan pada saat ini maupun di masa mendatang. Sehingga dapat dibedakan dengan pelatihan bahwa pengembangan merupakan proses pendidikan jangka panjang yang diterima karyawan dalam melaksanakan pekerjaan

Selain pelatihan dan pengembangan, dalam manajemen sumber daya manusia diperlukan reward dan punishment untuk menjaga produktivitas karyawan. Menurut Sinambela (2016) menjelaskan bahwa reward dapat merupakan salah satu atau kombinasi dari beberapa hal yaitu bayaran, benefit, dan reward non finansial bayaran yaitu berupa uang yang diterima oleh karyawan untuk melakukan kerja. Sedangkan benefit merupakan reward tambahan yang didapatkan karyawan selain dari bayaran yang diterima dan reward non finansial adalah rasa senang bekerja atau kepuasan karyawan dengan lingkungan tempat kerja yang memberikan aksesibilitas. Sedangkan punishment atau sanksi diberikan apabila karyawan melakukan sesuatu diluar aturan dan ketentuan organisasi yang berlaku. Sanksi diberikan untuk mengembalikan kinerja karyawan dan mempertahankan produktivitas karyawan sehingga dapat bekerja dengan baik sehingga dapat mencapai tujuan organisasi. Menurut Purwanto dalam Astuti (2018) menjelaskan bahwa pemberian sanksi atau punishment dapat dibagi atas dua bagian yaitu sanksi preventif dan sanksi represif. Sanksi preventif merupakan tindakan yang dilakukan oleh perusahaan atau organisasi untuk mencegah karyawan agar tidak melakukan pelanggaran meliputi tata tertib, anjuran dan perintah, larangan, paksaan, dan disiplin. Sedangkan sanksi represif merupakan tindakan yang diberikan oleh perusahaan kepada karyawan yang melakukan pelanggaran, meliputi: teguran, pemberhentian tunjangan, pemberhentian bonus, pembatasan penggunaan sarana dan prasarana perusahaan, dan pemutusan hubungan kerja. Tujuan penelitian ini adalah untuk mengetahui bagaimana pengaruh staffing pada proses rekrutmen, seleksi, pelatihan, reward dan punishment, serta pengembangan sebagai salah satu fungsi manajemen terhadap kinerja karyawan di Mitra Jaya Company.

\section{METODE PENELITIAN}

Metode yang digunakan dalam penelitian ini adalah deskriptif dengan pendekatan kuantitatif. Menurut Sugiyono (2012) menyatakan bahwa penelitian deskriptif yaitu penelitian yang dilakukan untuk mengetahui nilai variabel mandiri, baik satu variabel atau lebih (independen) tanpa membuat perbandingan, atau menghubungkan dengan variabel lain. Data yang diperoleh kemudian dianalisis secara deskriptif mencakup aspek - aspek dalam staffing terhadap kinerja karyawan.

\section{Sampel}

Sampel yang digunakan adalah sampel populasi. Teknik pengambilan sampel dalam penelitian ini adalah dengan menggunakan teknik sensus. Karena populasi yang diteliti kurang dari 100 (seratus) orang, sehingga sampel yang diambil berasal dari keseluruhan populasi yang berjumlah 30 (tiga puluh) orang karyawan. 


\section{Teknik Pengumpulan Data}

Pengumpulan data pada penelitian ini dilakukan dengan berbagai metode sebagai berikut:

\section{Kuisioner}

Peneliti memberikan kuisioner berupa daftar pernyataan kepada responden yang telah ditetapkan untuk menjadi sampel. Pernyataan yang ada di kuisioner berisi tentang variabel terkait penelitian ini yaitu rekrutmen $\left(\mathrm{X}_{1}\right)$, seleksi $\left(\mathrm{X}_{2}\right)$, pelatihan $\left(\mathrm{X}_{3}\right)$, reward dan punishment $\left(\mathrm{X}_{4}\right)$, dan pengembangan $\left(\mathrm{X}_{5}\right)$. Skala yang digunakan dalam kuisioner penelitian ini menggunakan skala likert. Kuisioner tersebut berisi pernyataan pernyataan yang dijawab oleh responden dengan menggunakan skala likert.

Tabel 1. Skala Likert

\begin{tabular}{|c|c|}
\hline Nilai & Kategori \\
\hline 1 & STS (Sangat Tidak Setuju) \\
\hline 2 & TS (Tidak Setuju) \\
\hline 3 & S (Setuju) \\
\hline 4 & SS (Sangat setuju) \\
\hline
\end{tabular}

Sumber: Budiaji (2013)

\section{Observasi}

Peneliti mencari data yang diperlukan sebagai bahan objek penelitian dengan melakukan pengamatan secara langsung bagaimana proses pembuatan mesin tetas telur dan manajemen sumber daya manusia untuk menjaga kinerja karyawan dalam proses pembuatan mesin tetas telur di Mitra Jaya Company.

\section{Wawancara}

Peneliti melakukan wawancara dengan direktur perusahaan untuk mengetahui informasi umum Mitra Jaya Company berupa jumlah karyawan, proses manajemen sumber daya manusia yang dilakukan, divisi - divisi yang ada di perusahaan, dan produk berupa mesin tetas telur yang dihasilkan

\section{Indikator Kinerja Karyawan}

Pada penelitian ini, untuk mengetahui kinerja karyawan di Mitra Jaya Company dalam menghasilkan mesin tetas telur digunakan beberapa indikator. Indikator dibuat untuk mengetahui pengaruh proses rekrutmen, seleksi, pelatihan, reward dan punishment, serta pengembangan sebagai variabel bebas terhadap kinerja karyawan sebagai variabel terikat. Indikator yang digunakan dalam penelitian ini untuk mengetahui kinerja karyawan dapat dilihat pada tabel 2.

Tabel 2. Indikator Kinerja Karyawan Karyawan

\begin{tabular}{|c|l|}
\hline 1 & $\begin{array}{l}\text { Saya mampu menyelesaikan pekerjaan dengan rapi dan ketelitian } \\
\text { yang tinggi. }\end{array}$ \\
\hline 2 & Saya memiliki pengetahuan atas pekerjaan yang saya lakukan. \\
\hline 3 & Saya mampu berinovasi dalam menyelesaikan pekerjaan \\
\hline
\end{tabular}




\begin{tabular}{|l|l|}
\hline 4 & Saya mampu bekerja dengan baik tanpa pengawasan pimpinan \\
\hline 5 & Saya mempunyai tanggung jawab dan komitmen dalam bekerja \\
\hline 6 & Saya pulang sesuai dengan jam kantor, kecuali karena lembur \\
\hline 7 & Saya selalu hadir ke lokasi tepat waktu \\
\hline & Sumber : Data diolah (2021)
\end{tabular}

\section{Analisis Data}

Peneleitian ini menggunakan beberapa uji untuk mengetahui dan menganilis.data yang diperoleh. Beberapa uji yang digunakan dalam penelitian ini diantaranya:

\section{Uji Validitas}

Uji validitas digunakan untuk mengukur sah atau valid tidaknya suatu angket. Dalam menggunakan pengujian validitas, digunakan alat ukur berupa program komputer yaitu SPSS (Statistical Product and Service Solutions). Uji validitas dilakukan dengan membandingkan nilai $r$ hitung dengan $r$ tabel untuk tingkat signifikansi 5 persen dari degree of freedom $(\mathrm{df})=\mathrm{n}-2$, dalam hal ini $\mathrm{n}$ adalah jumlah sampel. Jika $r$ hitung $>r$ tabel maka pertanyaan atau indikator tersebut dinyatakan valid, demikian sebaliknya bila $r$ hitung $<r$ tabel maka pertanyaan atau indikator tersebut dinyatakan tidak valid

\section{Uji Reliabilitas}

Uji reliabilitas merupakan alat untuk mengukur suatu kuesioner yang merupakan indikator dari variabel atau konstruk. Suatu kuesioner dikatakan reliabel atau andal jika jawaban seseorang terhadap pernyataan adalah konsisten atau stabil dari waktu ke waktu. Pengukuran reliabilitas dilakukan dengan metode one shot atau pengukuran sekali saja dengan aplikasi SPSS uji statistik Cronbach Alpha $(\alpha)$. Suatu konstruk atau variabel dikatakan reliabel jika memberikan nilai Cronbach Alpha > 0.60 (Nunnally dalam Ghozali, 2005)

\section{Analisis Regresi Linear Berganda}

Dalam penelitian ini, data diperoleh dengan pengisian kuisioner oleh karyawan Mitra Jaya Company. Kuisioner yang diberikan kepada responden digunakan untuk memperoleh data yang digunakan untuk mengetahui staffing sebagai salah satu fungsi manajemen terhadap kinerja karyawan di Mitra Jaya Company. Dalam penelitian ini, peneliti menggunakan uji regresi linier berganda.

Rumus persamaan regresi berganda adalah:

$$
Y=a+b_{1} x_{1}+b_{2} x_{2}+b_{3} x_{3}+b_{4} x_{4}+b_{5} x_{5}
$$

$\begin{array}{ll}\text { Keterangan: } & \\ \mathrm{Y} & : \text { Kinerja karyawan } \\ \mathrm{a} & : \text { Konstanta } \\ \mathrm{b}_{1}, \mathrm{~b}_{2}, \mathrm{~b}_{3}, \mathrm{~b}_{4}, \mathrm{~b}_{5} & : \text { Koefisien variabel } \\ \mathrm{X}_{1} & : \text { Rekrutmen } \\ \mathrm{X}_{2} & : \text { Seleksi } \\ \mathrm{X}_{3} & \text { : Pelatihan } \\ \mathrm{X}_{4} & \text { : Pengembangan }\end{array}$


$\mathrm{X}_{5} \quad:$ Reward dan punishment

\section{Uji Signifikansi Simultan (Uji F)}

Uji F digunakan untuk mengetahui signifikansi pengaruh variabel - variabel bebas secara bersama (simultan) terhadap variabel terikat. Hipotesis yang digunakan dalam penelitian ini adalah:

Ho: Variabel - variabel bebas yaitu rekrutmen, seleksi, pelatihan, pengembangan, serta reward dan punishment tidak memiliki pengaruh yang signifikan secara bersama terhadap variabel terikat yaitu kinerja karyawan.

Ha: Variabel - variabel bebas yaitu rekrutmen, seleksi, pelatihan, pengembangan, serta reward dan punishment memiliki pengaruh secara bersama terhadap variabel terikat yaitu kinerja karyawan.

Pengambilan keputusan berdasarkan pada penggunaan angka probabilitas signifikansi yaitu:

a. Apabila probabilitas signifikansi $>0.05$, maka Ho diterima dan Ha ditolak

b. Apabila probabilitas signifikansi $<0.05$, maka Ho ditolak dan Ha diterima.

\section{Uji Signifikansi Parsial (Uji T)}

Uji t digunakan untuk menguji signifikansi hubungan antara variabel $\mathrm{X}$ dan $\mathrm{Y}$, apakah variabel $\mathrm{X}_{1}, \mathrm{X}_{2}, \mathrm{X}_{3}, \mathrm{X}_{4}$ dan $\mathrm{X}_{5}$ (rekrutmen, seleksi, pelatihan, reward dan punishment, serta pengembangan) benar-benar berpengaruh terhadap variabel $\mathrm{Y}$ (kinerja karyawan) secara terpisah atau parsial. Hipotesis yang digunakan dalam pengujian ini adalah:

Ho: Variabel - variabel bebas (rekrutmen, seleksi, pelatihan, reward dan punishment, serta pengembangan) tidak mempunyai pengaruh yang signifikan terhadap variabel terikat (kinerja karyawan).

Ha: Variabel - variabel bebas (rekrutmen, seleksi, pelatihan, reward dan punishment, serta pengembangan) mempunyai pengaruh yang signifikan terhadap variabel terikat (kinerja karyawan).

Dasar pengambilan keputusan adalah dengan menggunakan angka probabilitas signifikansi, yaitu:

a. Apabila angka probabilitas signifikansi $>0,05$ dan $t_{\text {hitung }}<t_{\text {tabel }}$, maka Ho diterima dan Ha ditolak.

b. Apabila angka probabilitas signifikansi $<0,05$ dan $t_{\text {hitung }}>t_{\text {tabel }}$, maka Ho ditolak dan Ha diterima

\section{Analisis Koefisien Determinasi $\left(\mathbf{R}^{2}\right)$}

Koefisien determinasi $\left(\mathrm{R}^{2}\right)$ pada intinya mengukur seberapa jauh kemampuan model dalam menerangkan variasi variabel terikat. Nilai koefisien determinasi adalah antara nol dan satu. Nilai $R^{2}$ yang kecil berarti kemampuan variabel - variabel bebas dalam menjelaskan variasi variabel terikat amat terbatas. Begitu pula sebaliknya, nilai yang mendekati satu berarti variabel -variabel bebas memberikan hampir semua informasi yang dibutuhkan untuk memprediksi variasi variabel terikat. 


\section{HASIL PENELITIAN DAN PEMBAHASAN}

\section{Analisis Regresi Linier Berganda}

Analisis regresi linier berganda bertujuan untuk menganalisis hubungan dan pengaruh antara variabel bebas terhadap variabel terikat. Hasil analisis regresi linier berganda dihitung menggunakan bantuan SPSS 25 for windows. Hasil uji analisis regresi linier berganda dapat dilihat pada Tabel.

Tabel 3. Hasil Persamaan Regresi Linier Berganda

\begin{tabular}{|c|c|c|c|c|c|}
\hline \multirow[t]{2}{*}{ Model } & \multicolumn{2}{|c|}{$\begin{array}{c}\text { Unstandardized } \\
\text { Coefficients }\end{array}$} & \multirow{2}{*}{$\begin{array}{c}\text { Standardized } \\
\text { Coefficients }\end{array}$} & \multirow[t]{2}{*}{$\mathbf{T}$} & \multirow{2}{*}{ Sig. } \\
\hline & $\mathrm{B}$ & Std. Error & & & \\
\hline Konstanta & $-26,875$ & 16,379 & & $-1,641$ & 0,114 \\
\hline Rekrutmen & 1,700 & 0,579 & 0,587 & 2,936 & 0,007 \\
\hline Seleksi & 1,612 & 0,723 & 0,447 & 2,328 & 0,036 \\
\hline Pelatihan & $-0,064$ & 0,427 & $-0,031$ & $-0,149$ & 0,883 \\
\hline $\begin{array}{l}\text { Reward dan } \\
\text { Punishment }\end{array}$ & 1,177 & 0,693 & 0,331 & 1,699 & 0,102 \\
\hline Pengembangan & 0.146 & 0,275 & 102 & 0,531 & 0,601 \\
\hline \multicolumn{2}{|c|}{ Variabel Terikat } & \multicolumn{4}{|c|}{ Kinerja karyawan } \\
\hline \multicolumn{2}{|l|}{$\mathrm{R}$} & \multicolumn{4}{|c|}{0,685} \\
\hline \multicolumn{2}{|c|}{ R Square } & \multicolumn{4}{|c|}{0,469} \\
\hline \multicolumn{2}{|c|}{ Adjusted R Square } & \multicolumn{4}{|c|}{0,358} \\
\hline \multicolumn{2}{|c|}{$\mathrm{F}_{\text {Hitung }}$} & \multicolumn{4}{|c|}{4,235} \\
\hline \multicolumn{2}{|c|}{ Sig. F } & \multicolumn{4}{|c|}{0,007} \\
\hline
\end{tabular}

Sumber : Data diolah (2021)

Berdasarkan tabel maka didapatkan persamaan regresi linier berganda sebagai berikut

$$
\mathrm{Y}=-26,875+1,700 \mathrm{X} 1+1,612 \mathrm{X} 2+-0,64 \mathrm{X} 3+1,177 \mathrm{X} 4+0,146 \mathrm{X} 5
$$

Berdasarkan persamaan regresi tersebut, dapat diinterpretasikan sebagai berikut:

1. Konstanta $=-26,875$ artinya jika variabel rekrutmen (X1), seleksi (X2), pelatihan (X3), reward dan punishment (X4), serta pengembangan (X5) memiliki nilai nol maka kinerja karyawan memiliki nilai sebesar $-26,875$

2. Rekrutmen $(\mathrm{X} 1)=1,700$ artinya variabel rekrutmen $(\mathrm{X} 1)$ berpengaruh positif dan memiliki hubungan searah dengan kinerja karyawan (Y). Hal ini menunjukan bahwa, apabila variabel rekrutmen (X1) menunjukan kenaikan satu satuan, maka akan diikuti kenaikan pada variabel kinerja karyawan (Y) sebesar 1,700 dengan asumsi variabel bebas yang lain tetap.

3. Seleksi $(\mathrm{X} 2)=1,612$ artinya variabel seleksi (X2) berpengaruh positif dan memiliki hubungan searah dengan kinerja karyawan (Y). Hal ini menunjukan bahwa, apabila variabel seleksi (X2) menunjukan kenaikan satu satuan, maka 
akan diikuti kenaikan pada variabel kinerja karyawan (Y) sebesar 1,612 dengan asumsi variabel bebas yang lain tetap.

4. Pelatihan $(X 3)=-0,64$ artinya variabel pelatihan $(X 3)$ berpengaruh negatif dan memiliki hubungan yang tidak searah dengan kinerja karyawan. Hal ini menunjukan bahwa, apabila variabel pelatihan (X3) menunjukan kenaikan satu satuan maka akan diikuti dengan penurunan pada variabel kinerja karyawan (Y) sebesar -0,64 dengan asumsi variabel bebas yang lain tetap.

5. Reward dan punishment $(\mathrm{X} 4)=1,177$ artinya variabel reward dan punishment berpengaruh positif dan memiliki hubungan searah dengan kinerja karyawan (Y). Hal ini menunjukan bahwa, apabila variabel reward dan punishment menunjukan kenaikan satu satuan, maka akan diikuti kenaikan pada variabel kinerja karyawan (Y) sebesar 1,177 dengan asumsi variabel bebas yang lain tetap.

6. Pengembangan $(X 5)=0,146$ artinya variabel pengembangan memiliki pengaruh yang positif dan memiliki hubungan searah dengan kinerja karyawan (Y). Hal ini menunjukan bahwa, apabila variabel pengembangan menunjukan kenaikan satu satuan, maka diikuti kenaikan pada variabel kinerja karyawan sebesar 0,146 dengan asumsi variabel bebas yang lain tetap.

\section{Hipotesis Penelitian}

Uji hipotesis bertujuan untuk melihat bagaimana pengaruh variabel bebas yaitu rekrutmen, seleksi, pelatihan, reward dan punishment, serta pengembangan terhadap variabel terikat yaitu kinerja karyawan. Uji hipotesis dalam penelitian ini terdiri dari Uji Signifikansi Simultan (Uji Statistik F), Analisis Koefisien Determinasi ( $\left.\mathrm{R}^{2}\right)$, dan Uji Signifikansi Pengaruh Parsial (Uji t), Berikut hasil uji hipotesis pada penelitian ini:

\section{Uji Signifikansi Simultan (Uji Statistik F)}

Uji signifikansi simultan (Uji statistik F) Uji F digunakan untuk menguji apakah seluruh variabel bebas secara bersama-sama memiliki pengaruh terhadap variabel terikat. Jika nilai $F_{\text {hitung }}>$ nilai $F_{\text {tabel }}$ dan nilai signifikansi $<0,05$ maka seluruh variabel bebas berpengaruh secara bersama-sama terhadap variabel terikat. Nilai $F_{\text {tabel }}$ pada penelitian ini sebesar 2,60.

Berdasarkan Tabel diketahui bahwa variabel bebas (rekrutmen, seleksi, pelatihan, reward dan punishment, serta pengembangan) secara bersama-sama memiliki pengaruh yang signifikan terhadap variabel terikat (kinerja karyawan). Hal tersebut dibuktikan dari nilai $F_{\text {hitung }}$ sebesar 4,235 (> 2,60), dengan nilai signifikansi sebesar 0,007 (< 0,05). Berdasarkan hasil uji $\mathrm{F}$ tersebut, dapat disimpulkan bahwa $H_{0}$ ditolak dan $H_{a}$ diterima yang artinya variabel rekrutmen (X1), seleksi (X2), pelatihan (X3), reward dan punishment (X4), serta pengembangan (X5) secara bersama-sama berpengaruh signifikan terhadap variabel kinerja karyawan (Y) dalam memproduksi mesin tetas telur. 


\section{Uji Signifikansi Pengaruh Parsial (Uji t)}

Uji t digunakan untuk menguji pengaruh dari masing-masing variabel bebas terhadap variabel terikat. Jika nilai $t_{\text {hitung }}>$ nilai $t_{\text {tabel }}$ dan nilai signifikansi $<0,05$ maka variabel bebas berpengaruh terhadap variabel terikat. Nilai $t_{\text {tabel }}$ pada penelitian ini adalah 2,064. Berdasarkan tabel maka diperoleh hasil uji t untuk masing - masing variabel sebagai berikut:

\section{Pengaruh variabel Rekrutmen $\left(\mathrm{X}_{1}\right)$ terhadap Kinerja Karyawan (Y)}

Hasil uji $\mathrm{t}$ antara variabel rekrutmen $\left(\mathrm{X}_{1}\right)$ terhadap variabel kinerja karyawan $(\mathrm{Y})$ menunjukkan nilai $t_{\text {hitung }}$ sebesar 2,936 (> 2,064), dengan nilai signifikansi sebesar $0,007$ (< 0,05$)$. Hasil tersebut menyatakan bahwa $H_{0}$ ditolak dan $H_{a}$ diterima, yang artinya variabel rekrutmen $\left(\mathrm{X}_{1}\right)$ berpengaruh secara signifikan terhadap variabel kinerja karyawan (Y). Variabel rekrutmen memiliki pengaruh sebesar 1,7 terhadap variabel kinerja karyawan.

\section{Pengaruh variabel Seleksi $\left(\mathrm{X}_{2}\right)$ terhadap Kinerja Karyawan (Y)}

Hasil uji $\mathrm{t}$ antara variabel seleksi $\left(\mathrm{X}_{2}\right)$ terhadap variabel kinerja karyawan (Y) menunjukkan nilai $t_{\text {hitung }}$ sebesar 2,228 (> 2,064), dengan nilai signifikansi sebesar $0,036(<0,05)$. Hasil tersebut menyatakan bahwa $H_{0}$ ditolak dan $H_{a}$ diterima, yang artinya variabel seleksi $\left(\mathrm{X}_{2}\right)$ berpengaruh secara signifikan terhadap variabel kinerja karyawan (Y). Variabel seleksi memiliki pengaruh sebesar 1,612 terhadap variabel Kinerja Karyawan.

\section{Pengaruh variabel Pelatihan (X3) terhadap Kinerja Karyawan (Y)}

Hasil uji $\mathrm{t}$ antara variabel pelatihan $\left(\mathrm{X}_{3}\right)$ terhadap variabel kinerja karyawan $(\mathrm{Y})$ menunjukkan nilai $t_{\text {hitung }}$ sebesar $-0,149(<2,064)$, dengan nilai signifikansi sebesar $0,883(<0,05)$. Hasil tersebut menyatakan bahwa $H_{a}$ ditolak dan $H_{0}$ diterima, yang artinya variabel pelatihan $\left(\mathrm{X}_{3}\right)$ tidak memiliki pengaruh terhadap variabel kinerja karyawan $(\mathrm{Y})$. Variabel pelatihan memiliki pengaruh sebesar -0,064 terhadap variabel kinerja karyawan.

\section{Pengaruh variabel Reward dan Punishment ( $\left.\mathrm{X}_{4}\right)$ terhadap Kinerja Karyawan (Y)}

Hasil uji t antara variabel reward dan punishment $\left(\mathrm{X}_{4}\right)$ terhadap variabel kinerja karyawan (Y) menunjukkan nilai $t_{\text {hitung }}$ sebesar 1,699 $(<2,064)$, dengan nilai signifikansi sebesar 0,102 $(<0,05)$. Hasil tersebut menyatakan bahwa $H_{a}$ ditolak dan $H_{0}$ diterima, yang artinya variabel reward dan punishment $\left(\mathrm{X}_{4}\right)$ tidak memiliki pengaruh terhadap variabel kinerja karyawan (Y). Variabel reward dan punishment memiliki pengaruh sebesar 1,177 terhadap variabel kinerja karyawan.

\section{Pengaruh variabel Pengembangan $\left(\mathrm{X}_{5}\right)$ terhadap Kinerja Karyawan $(\mathrm{Y})$}

Hasil uji t antara variabel pengembangan $\left(\mathrm{X}_{5}\right)$ terhadap variabel kinerja karyawan (Y) menunjukkan nilai $t_{\text {hitung }}$ sebesar $0,531(<2,064)$, dengan nilai signifikansi sebesar 0,601 $(<0,05)$. Hasil tersebut menyatakan bahwa $H_{a}$ ditolak dan 
$H_{0}$ diterima, yang artinya variabel pengembangan $\left(\mathrm{X}_{5}\right)$ tidak memiliki pengaruh terhadap variabel kinerja karyawan (Y). Variabel pengembangan memiliki pengaruh sebesar 0,146 terhadap variabel kinerja karyawan.

\section{Analisis Koefisien Determinasi $\left(\mathbf{R}^{\mathbf{2}}\right)$}

Uji Koefisien Determinasi digunakan untuk mengukur seberapa besar pengaruh variabel bebas terhadap variabel terikat. Nilai koefisien determinasi antara nol sampai satu $(0<$ $R^{2}<1$ ). Jika nilai koefisien determinasi mendekati satu, maka kemampuan variabel bebas dalam menerangkan variabel terikat sangatlah kuat.

Berdasarkan Tabel diketahui bahwa nilai koefisien determinasi yang diperoleh pada penelitian ini sebesar 0,469. Hal tersebut menunjukkan bahwa 46,9\% Kinerja Karyawan dalam memproduksi mesin tetas telur di Mitra Jaya Company dapat dijelaskan oleh variabel rekrutmen, seleksi, pelatihan, reward dan punishment, serta pengembangan, sedangkan sisanya yaitu sebesar 53,1\% kinerja karyawan Mitra Jaya Company dijelaskan oleh variabel-variabel lain yang tidak dijelaskan dalam penelitian ini.

Koefisien korelasi digunakan untuk melihat besarnya hubungan antara variabel bebas dengan variabel terikat. Berdasarkan Tabel diketahui nilai koefisien korelasi pada penelitian ini sebesar 0,685. Hasil tersebut menunjukkan bahwa hubungan antara variabel bebas (rekrutmen, seleksi, pelatihan, reward dan punishment, serta pengembangan) dengan variabel terikat yaitu kinerja karyawan berada pada kategori sedang.

\section{KESIMPULAN}

Berdasarkan hasil dari penelitian, pembahasan serta temuan yang ada di lapang, maka kesimpulan yang didapatkan dari penelitian ini adalah sebagai berikut:

1. Variabel bebas rekrutmen $\left(\mathrm{X}_{1}\right)$, seleksi $\left(\mathrm{X}_{2}\right)$, pelatihan $\left(\mathrm{X}_{3}\right)$, reward dan punishment $\left(\mathrm{X}_{4}\right)$, serta pengembangan $\left(\mathrm{X}_{5}\right)$ secara bersama-sama berpengaruh signifikan terhadap variabel kinerja karyawan (Y) dalam menghasilkan mesin tetas telur yang berkualitas berdasarkan hasil uji signifikansi simultan.

2. Variabel rekrutmen dan seleksi karyawan menunjukan pengaruh yang signifikan terhadap kinerja karyawan di Mitra Jaya Company dalam menghasilkan mesin tetas telur yang berkualitas.

3. Variabel pelatihan karyawan menunjukan bahwa tidak memiliki pengaruh terhadap kinerja karyawan Mitra Jaya Company.

4. Variabel Reward dan punishment serta variabel pengembangan memiliki pengaruh yang tidak signifikan terhadap kinerja karyawan di Mitra Jaya Company.

\section{DAFTAR PUSTAKA}

Anawati, L., S. Ngumar. 2016. Audit Manajemen Untuk Mengevaluasi Efektivitas dan Efisiensi Rekrutmen Sumber Daya Manusia. Jurnal Ilmu dan Riset Akuntansi.5 (1): 1 - 15.

Astuti, W. S., H. Sjahruddin. dan S. Purnomo. 2018. Pengaruh Reward dan Punishment Terhadap Kinerja Karyawan. Jurnal Organisasi dan Manajemen. 31 - 46. 
Budiaji, W. 2013. Skala Pengukuran dan Jumlah Respon Skala Likert. Jurnal Ilmu Pertanian dan Perikanan. 2 (2): 127 - 133.

Findarti, F. R., 2016. Pengaruh Pengembangan Sumber Daya Manusia Terhadap Kinerja Pegawai Pada Kantor Badan Kepegawaian Daerah Provinsi Kalimantan Timur. Jurnal Ilmu Administrasi Bisnis. 4 (4): 937 - 946.

Firmansyah, M. A., dan B.W. Mahardika. 2018. Pengantar Manajemen. [PDF]. Yogyakarta: Deepublish.

Lolowang, M. G., Adolfina, G. Lumintang. 2016. Pengaruh Pelatihan dan Pengembangan Sumber Daya Manusia Terhadap Kinerja Karyawan Pada PT. Berlian Kharisma Pasifik

Manado. Jurnal EMBA. 4 (2): 177 - 186.

Muhlis, M., Soepeno, R. T. K. Rinda. 2018. Pelatihan dan Pemotivasian Terhadap Pengembangan Karir Karyawan. Jurnal Ilmu Manajemen. 1 (1): 44 - 56.

Purwati, A. A., H. Satria. 2017. Pengaruh Perekrutan, Motivasi, dan Pelatihan Terhadap Kinerja Karyawan Pada CV. Skala Sport Pekanbaru. Procuratio. 5 (4): 418 - 429.

Sinambela, L. P., 2016. Manajemen Sumber Daya Manusia.

Sugiyono, 2013. Metode Penelitian Kuantitatif Kualitatif dan R\&D. [PDF]. Bandung: Alfabeta.

Sunarsi, D. 2018. Pengaruh Rekrutmen, Seleksi, dan Pelatihan Terhadap Produktivitas Kerja Karyawan. Jurnal Kreatif : Pemasaran, Sumber Daya Manusia dan Keuangan. 6 (1): 1431 